\title{
Natural Products for Managing Landscape and Garden Pests in Florida ${ }^{1}$
}

\author{
Matthew A. Borden, Eileen A. Buss, Sydney G. Park Brown, and Adam G. Dale 2
}

Pest control professionals and homeowners throughout Florida and the southeastern US are seeking effective options that are safer for people and the environment than some conventional synthetic pesticides. There is also rising interest in organic gardening, which relies on natural pesticides. See the Organic Materials Review Institute (OMRI) website (https://www.omri.org/omri-lists/ download) for products that are acceptable in organic plant production. Natural or biological pesticides, also called biopesticides, can be used by themselves or in combination with conventional pesticide programs as valuable rotation options, thus delaying or preventing onset of resistance caused by repeated use of the same chemical controls.

This publication describes natural products for use in residential landscapes and gardens. They are generally less toxic to nontarget organisms and the environment and, when used correctly, can be effective tools for plant protection. These products are most effective when used in an integrated pest management (IPM) program along with sanitation, proper cultural practices, mechanical control tactics, use of resistant plant varieties, and biological control (Figures 1 and 2).

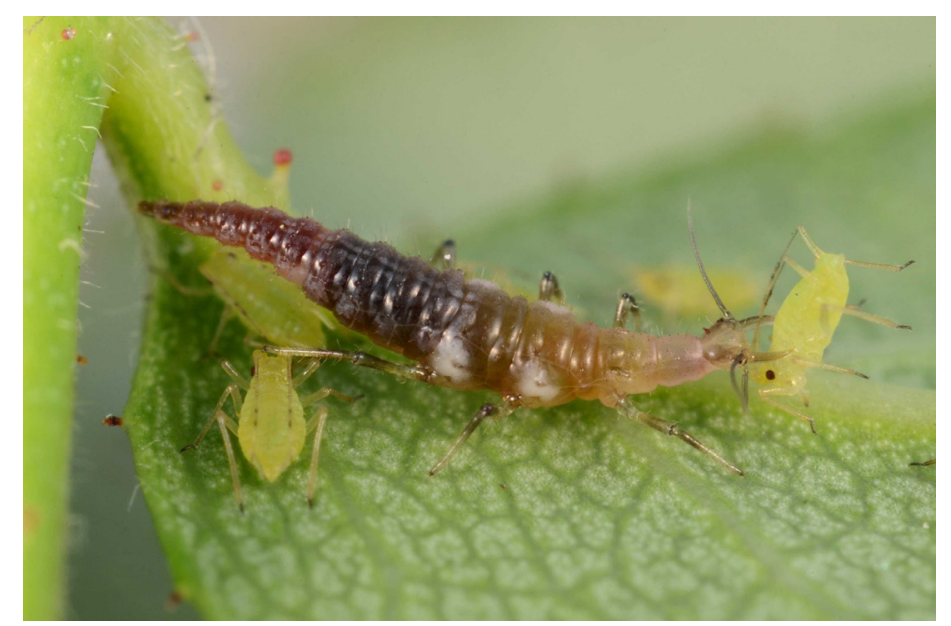

Figure 1. A brown lacewing larva, Micromus posticus, feeding on aphid pests of a rose bush. This soft-bodied predator would likely be killed by natural insecticides intended for the aphids.

Credits: Lyle Buss, UF/IFAS

There is a general lack of knowledge about natural or biological pesticides, including commercial availability and effective use. All pesticides, whether natural or synthetic, carry inherent risks and require safe and responsible use by the applicator. Ideally, natural insecticides and fungicides should reduce insect or disease problems, be specific to the

1. This document is ENY-350, one of a series of the Department of Entomology and Nematology, UF/IFAS Extension. Original publication date January 2002. Revised September 2018. Visit the EDIS website at http://edis.ifas.ufl.edu.

2. Matthew A. Borden, graduate research assistant; Eileen A. Buss, associate professor emeritus, Department of Entomology and Nematology; Sydney G. Park Brown, associate professor emeritus, Environmental Horticulture Department, UF/IFAS Gulf Coast Research and Education Center; and Adam G. Dale, assistant professor, Department of Entomology and Nematology; UF/IFAS Extension, Gainesville, FL 32611.

The use of trade names in this publication is solely for the purpose of providing specific information. UF/IFAS does not guarantee or warranty the products named, and references to them in this publication do not signify our approval to the exclusion of other products of suitable composition. All chemicals should be used in accordance with directions on the manufacturer's label. Use pesticides safely. Read and follow directions on the manufacturer's label.

The Institute of Food and Agricultural Sciences (IFAS) is an Equal Opportunity Institution authorized to provide research, educational information and other services

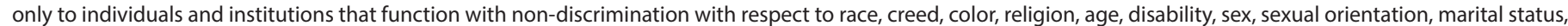

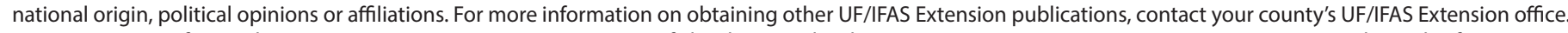
U.S. Department of Agriculture, UF/IFAS Extension Service, University of Florida, IFAS, Florida A \& M University Cooperative Extension Program, and Boards of County Commissioners Cooperating. Nick T. Place, dean for UF/IFAS Extension. 


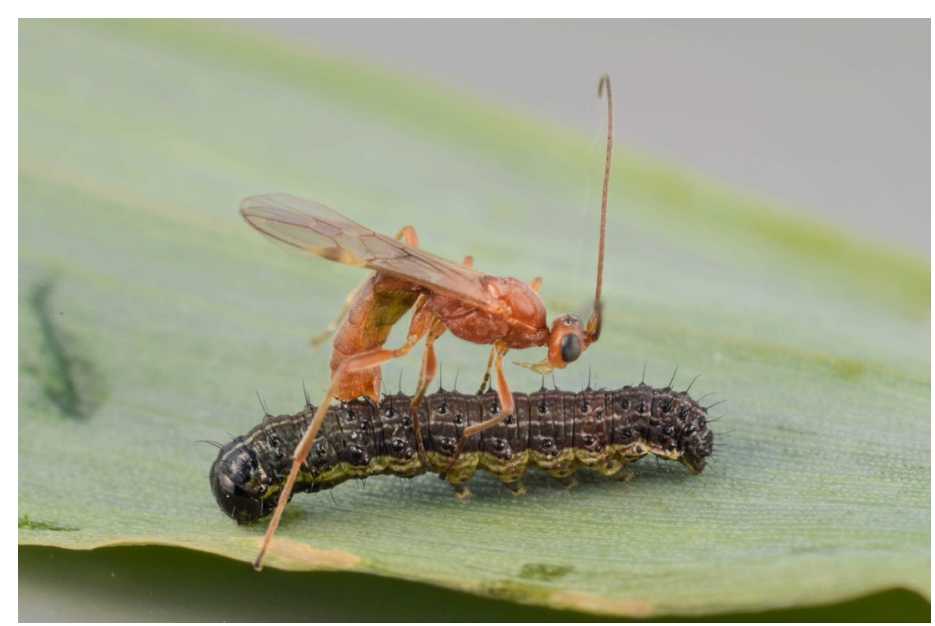

Figure 2. A beneficial wasp, Aleiodes laphygmae, parasitizing a fall armyworm caterpillar pest. This hard-bodied, flying adult wasp is likely to survive after a natural insecticide application.

Credits: Lyle Buss, UF/IFAS

pest(s), break down quickly, have low mammalian toxicity, and have minimal impact on the environment. General traits of natural products include the following:

Fast breakdown. Most natural products degrade rapidly in sunlight, air, or moisture, or when exposed to insect detoxification enzymes if ingested. Rapid breakdown means these products do not persist long in the environment, which reduces risk to nontarget organisms. However, it also means precise timing and more frequent applications may be necessary.

Fast action. Some natural products, such as soaps and oils, kill insects upon contact. Ingestion of others (e.g., Bacillus thuringiensis and spinosad) causes pests to quickly stop feeding, although death may not occur until hours or days later.

Low toxicity. Most of the natural products discussed here have low to moderate acute mammalian toxicity. Although these products are relatively safe if used properly, they should be handled with the same level of caution used for any other pesticide. Follow the manufacturer's instructions when using these products, and utilize personal protection equipment when necessary.

Gardeners should also be aware of potential disadvantages of natural products, which may include the following:

Phytotoxicity. Vegetables and ornamental plants can be damaged by insecticidal soaps, horticultural oils, plant oils, and sulfur, especially at higher rates or application frequency. The effects are likely more pronounced for stressed plants and in hot, sunny conditions. Carefully read the label instructions on how to avoid injuring the plants.

Cost and availability. Natural products, especially OMRIapproved versions, are sometimes more expensive than conventional pesticides, and some are hard to obtain. In addition, due to different producers and the biological nature of these products, the potency of some natural products may vary from one source or batch to the next.

State registration. Many pesticides registered by the United States Environmental Protection Agency (EPA) can be purchased online but are not registered for legal sale in certain states. If users are not sure whether a product is legal to use in Florida, they may direct questions regarding specific brand registration status to FDACS at 850-6177940 or AESCares@FreshFromFlorida.com. Alternatively, search the National Pesticide Information Retrieval System (http://npirspublic.ceris.purdue.edu/state/state_menu. aspx?state=FL) for Florida products.

Lack of EPA review. Many natural ingredients used to make pesticides are exempt from the rigorous review process usually required by the EPA. Data on pest control efficacy, long-term health effects, and tolerances for residues on food crops have not been established. Additional information on biopesticide development and efficacy trials is available for certain products at The IR-4 Project website (https://www.ir4project.org/ about-biopesticide-organic-support-4).

\section{Oils (Plant- and Petroleum- Derived)}

In general, oils are most effective against small, soft-bodied insects and mites that are immobile or slow-moving (e.g., aphids, scales, leafhopper nymphs, whiteflies). The target pests should be thoroughly covered by the oil spray. Oils lack residual activity, so they cannot prevent insect reinvasion and often need to be frequently reapplied. Oils affect insects and mites in several ways. When sprayed onto insects, plant and petroleum oils can block the insects' breathing holes (spiracles) and cause them to suffocate. Oils can prevent gas exchange through egg membranes, so eggs are also targets of control with oils. The fatty acids in plant oils may disrupt cell membranes and interfere with insect or mite metabolism. Some oils may also have repellent or anti-feeding properties, which can help reduce colonization by more mobile insects. Mineral oils called stylet oils interfere with virus transmission of insect vectors such as aphids and leafhoppers, reducing the chance of plant infection. 


\section{Citrus Oils-Limonene and Linalool}

Citrus oils, which are extracted from oranges and other citrus fruit peels (Figure 3), are used extensively as flavorings and scents in foods, cosmetics, soaps, and perfumes. Both compounds have low oral and dermal toxicities and are generally recognized as safe for mammals by the United States Food and Drug Administration.

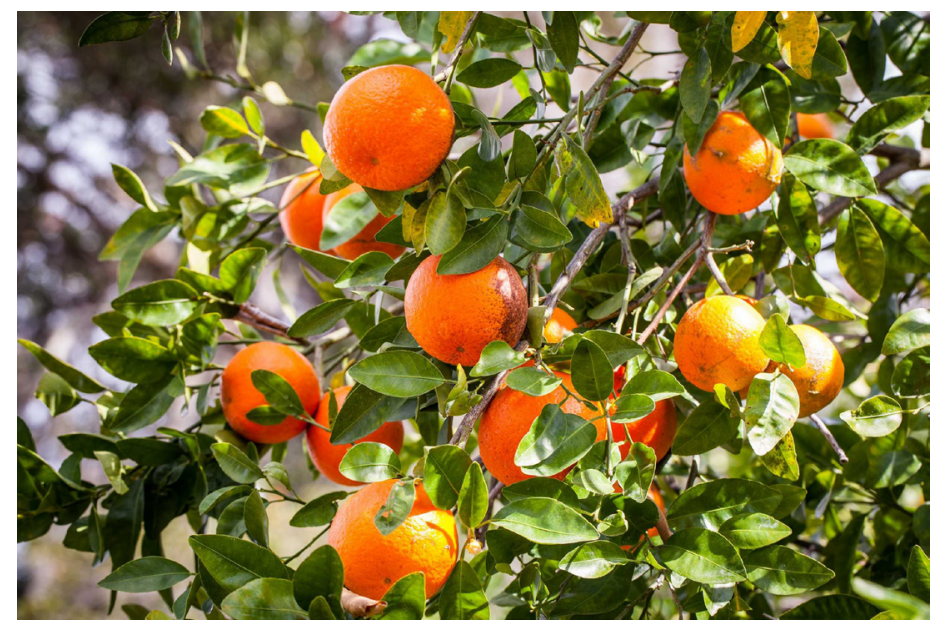

Figure 3. Citrus oils from fruit peels are used to make the insecticidal compounds d-limonene and linalool.

Credits: Matthew Borden, UF/IFAS

The oils can also be refined to make the compounds d-limonene and linalool, which are used as insecticides. Limonene and linalool are contact poisons (nerve toxins) that may be synergized by piperonyl butoxide (PBO) (see the "Pyrethrum/Pyrethrins" section). Both compounds evaporate readily from treated surfaces and have no residual activity. They have been registered for use against fleas, aphids, and mites, but they also kill fire ants, several types of flies, paper wasps, and house crickets. Commercial products (usually containing d-limonene) are available as liquids, aerosols, shampoos, and dips for pets. Contact with skin or eyes can be irritating to some animals, but symptoms are usually temporary. Use with caution to minimize phytotoxicity to new or sensitive plants.

\section{Neem}

Neem oil is extracted from seeds of the neem tree, Azadirachta indica, which is native to India. Pure neem oil, often called cold pressed neem oil, contains several insecticidal and fungicidal chemical compounds, including azadirachtin, salannin, and many others that have not been as well-studied. This oil can be processed into several types of products, which are collectively referred to as "neem" but have different uses and components.
For the most common type of product, an extraction process removes the primary insecticide, azadirachtin, and related compounds. Once processed, the resulting oil is called clarified hydrophobic extract of neem oil. However, both this form and the original oil, which can include azadirachtin, are usually referred to as neem oil. These products are commonly sold at garden centers and contain mainly fatty acids and glycerides. They function like insecticidal soap (potassium salts of fatty acids) and other horticultural oils, requiring direct contact and thorough coverage to effectively smother and kill pests. Similarly, they work best against soft-bodied pests, such as aphids, whiteflies, spider mites, and mealybug and scale nymphs. Certain neem oil products are also labeled for prevention of several foliar plant diseases, including powdery mildew and some rusts.

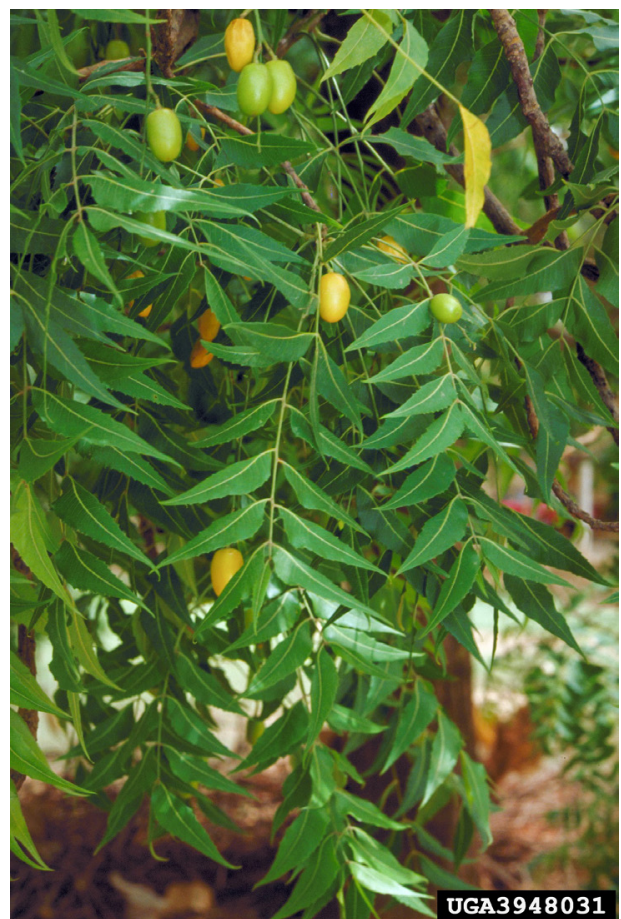

Figure 4. Neem oil comes from the seeds of the neem tree, Azadirachta indica.

Credits: William M. Ciesla, Forest Health Management International, used here under Creative Commons license CC BY-NC 3.0 US. Source: bugwood.org

Another type of neem product makes use of concentrated azadirachtin after it is separated from the neem oil. Azadirachtin is used to control a wide range of pests, including caterpillars, sawflies, flea beetles, weevils, aphids, and leafhoppers. Azadirachtin can control several insect groups by acting as a feeding deterrent, deterrent to egg-laying, repellent, direct toxin, or insect growth regulator. These products work well against the immature stages of chewing 
pests. After ingesting a treated plant, the juvenile insect may be unable to molt to its next life stage and die within a few days. Azadirachtin has some systemic activity when applied to roots and is weakly systemic in leaves, allowing it to control leafminers. Some products may be labeled for use as a soil drench for pests such as fungus gnats. Although neem-based, these products are not intended for disease control of any kind.

Different neem products can vary considerably in their activity. Thus, if one product does not work, it may be worthwhile to try another. This is especially true with products in which the active ingredient is simply listed as azadirachtin, in which case an alternative product listing neem oil may work better. Neem products have low mammalian toxicity and do not cause skin irritation in most formulations; however, individual labels will still indicate rules for safe handling and legal application. Neem oil products sold as cosmetics or as medicinal essential oils should never be used interchangeably with neem products sold as pesticides.

\section{Other Plant Oils Used As Insecticides and/ or Repellents}

Many products containing highly concentrated plant oils besides citrus and neem are commercially available, and are often referred to as essential oils. These are usually combinations of different plant oils, plant oils combined with plant extracts such as pyrethrins, and plant oils combined with fish oil. These products are promoted as insecticides, insect repellents, or both. Many of these oils have bioactive components, providing toxicity to pests beyond simply smothering them. They may be able to affect larger insects, whereas other horticultural oils are more limited to small and soft-bodied insects. However, there is a lack of consistency among products, as well as large natural variation among essential oil compositions. Since the oils may work well against certain insects but not others, treatments should be observed for efficacy.

The most common oils used in these products are sesame, garlic, canola, and soybean. Some herbal extracts include oils from thyme, rosemary, peppermint, cinnamon, and clove. Others-such as cedar, lavender, eucalyptus, pennyroyal, and citronella-are commonly used as flea and mosquito repellents on pets and humans, but their effectiveness varies depending on the plant compounds, concentration, application method, and product formulation used. Maia and Moore (2011) provide a review of plant-based mosquito repellents and their potential risks. Most common oils are regarded as low-risk to humans and pets when applied as recommended. An exception is pennyroyal, which is highly toxic when ingested.

\section{Horticultural Oils}

Horticultural oils (often called hort oils, spray oils, or summer/dormant oils) are highly refined, lightweight oils that are most often derived from petroleum. The oil is mixed with water and sprayed as a fine mist onto plant foliage and bark. When used correctly, horticultural oils can help manage many piercing-sucking insects and mites. They work best against small, soft-bodied insects such as aphids, whitefly nymphs, mealybug nymphs, and scale insect nymphs. The oils are much less effective against hard-bodied adult insects, or insects protected by a waxy covering, such as adult scale insects.

Oils must fully coat the target pest; therefore, thorough coverage of the undersides of leaves where the insects live is often necessary. If a plant is dormant (not actively growing), a higher concentration of horticultural oil may be used to control overwintering mites or insects. If a plant is actively growing or blooming, a lower concentration should be used to reduce the risk of phytotoxicity (pitting, spotting, or chemical burn) on sensitive plants. Read the label for detailed rate instructions.

Avoid horticultural oil applications when outdoor temperatures exceed $90^{\circ} \mathrm{F}$. Do not use on waxy succulents or other sensitive plants indicated on the label. When used correctly, horticultural oils and insecticidal soaps provide effective control for many pests, yet have extremely low toxicity and no residual effect after the spray has dried.

\section{Insecticidal Soap}

Insecticidal soaps, containing potassium salts of fatty acids, are made by adding potassium hydroxide to salts of fatty acids, which are found in fats and oils of animals (lard, fish oil) and plants (cottonseed, olive, palm, or coconut). The resulting soap products are useful against soft-bodied pests such as aphids, soft scales, psyllids, whiteflies, mealybugs, thrips, and spider mites.

While the mode of action is not fully understood, insecticidal soaps are thought to work by penetrating and disrupting the insects' cell membranes, removing protective waxes from the outer cuticle and causing dehydration, and blocking breathing holes to cause suffocation. Insecticidal soaps have many similarities to horticultural oils in their application and precautions. Like oils, soap sprays must contact the insect directly to be effective, and residues that remain on plants after drying have no insecticidal effect. A 
difference is that horticultural oil is slightly more effective against armored scale insects, while insecticidal soap is preferable for soft scale insects. Plants with hairy leaves or plants that are suffering from drought stress may be more sensitive to soaps. Check the product label to find a list of plants that may be sensitive. Spray the soap onto a small area of a plant first and wait for a day to ensure the product does not burn the leaves.

Insecticidal soaps are chemically similar to other household soaps, but are designed for pest control on plants. In general, while other soaps found in the home can kill insects, they are often not as effective and pose greater risk of injury to the plant. Dish soaps designed to strip grease and oils off kitchenware may be particularly harsh, as they are not true soaps but instead contain synthetic detergents. Because detergents and other household soaps are neither designed nor labeled for use on plants or in pest control, their use is not recommended.

\section{Plant Extracts}

\section{Pyrethrum/Pyrethrins}

Pyrethrins are highly concentrated compounds extracted from the daisy-like flower of Chrysanthemum cinerariaefolium (Figure 5), commercially grown in Kenya. When the flower is ground into a powder, the product is called a pyrethrum. Pyrethrins may be used against a broad range of pests, such as ants, roaches, fleas, flies, ticks, and garden pests. They are available in dusts, sprays, and aerosol "bombs," and are often mixed with synthetic pesticides or other natural products. Do not confuse the similar-sounding pyrethroids (e.g., bifenthrin, cyfluthrin, permethrin, and others) with pyrethrins. Pyrethroids are relatively long-lasting synthetic insecticides that have the same mode of action as pyrethrins but may pose greater risks to predator and parasitoid insects.

Many insect groups are susceptible to low concentrations of pyrethrins. The toxins act rapidly on contact, quickly reaching the insect nervous system to cause knockdown or paralysis; however, insects may metabolize them and recover. To prevent recovery, a synergist (a substance that works with a product to increase its effectiveness) such as piperonyl butoxide (PBO) or MGK 264 is often included in the mixture. Products containing these synergists should not be mixed with lime or soap solutions due to accelerated breakdown. Most synergists have low toxicity, little to no insecticidal properties of their own, and very short residual activity. In addition to their action as insecticides, pyrethrins (and some pyrethroids) have repellent properties.
Pyrethrins break down quickly, have short residual activity, and have low mammalian toxicity, making them among the safest insecticides in use. However, they cause allergic skin reactions in some people, and cats are highly susceptible to poisoning (e.g., flea drops and powder). Pyrethrins are toxic to fish, so use caution when applying these products near water sources.

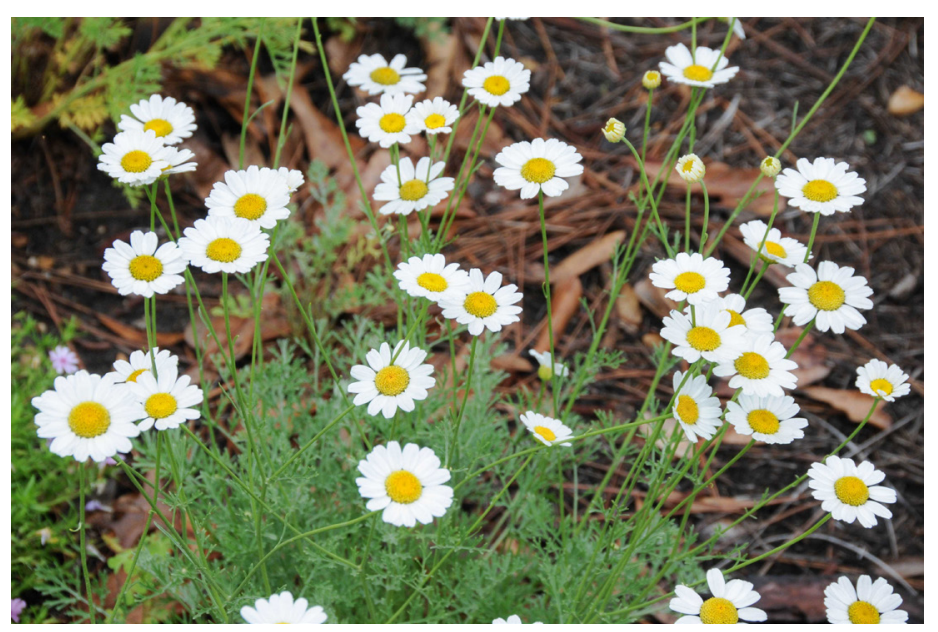

Figure 5. Pyrethrins are extracted from Chrysanthemum cinerariaefolium.

Credits: Blake Layton, Mississippi State University

\section{Rotenone, Ryania, Sabadilla, and Nicotine}

Rotenone, ryania, sabadilla, and nicotine are all plant extracts that were once common botanical insecticides. However, they are not currently registered or available for landscape and garden use in Florida. Ryania and sabadilla have very low human toxicity. On the other hand, rotenone poses significant health risks to mammals and other nontarget organisms, especially fish. Nicotine is also highly toxic to humans, both orally and dermally. For reasons of legal registration and toxicity, their use is not recommended.

\section{Hot Pepper}

Products made with hot peppers (Figure 6) contain capsaicinoids, the primary compounds that give peppers their "heat." Low doses of capsaicinoids from cayenne peppers are often combined with paraffin and sold as "hot pepper wax" repellents for insects and other animals. The flavor does not affect the taste of fruits or vegetables that have been treated. However, there is some doubt about their effectiveness. The extracts of whole hot pepper fruits have shown toxicity and repellency to caterpillar pests and spider mites, but the effect was due to other compounds in the fruit extracts, not the primary capsaicinoids. 


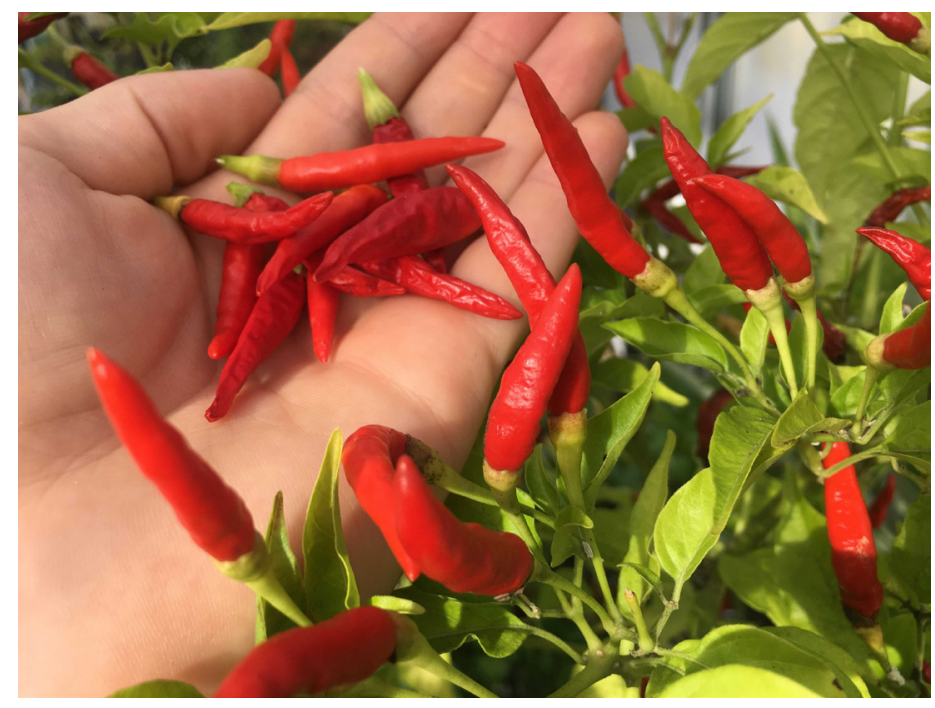

Figure 6. Hot pepper products containing capsaicinoids claim to repel certain insects.

Credits: Matthew Borden, UF/IFAS

\section{Mineral Insecticides Diatomaceous Earth}

Diatomaceous earth (DE) is mined from the fossilized silica shell remains of diatoms (single-celled aquatic algae). The particles have sharp edges that abrade and absorb the water-protecting oils and waxes from an insect's outer body, causing it to dehydrate and eventually die. Products are usually designed for use against indoor and structural pests, such as ants, fleas, bed bugs, and cockroaches. DE is said to be useful against garden organisms that are sensitive to desiccation, such as slugs, snails, and small insects. However, evaluations (Capinera 2018) show it is not practical for outdoor insects, and molluscs are generally not killed or repelled from feeding. One problem is that it must remain completely dry to be effective. This makes it very difficult to use in Florida's humid climate.

Several kinds of DE are available, but many products are not designed for pesticide use. "Natural grade" (amorphous) DE is used for food grade and insecticidal products. Insecticidal DE has very low mammalian toxicity, but as a fine dust it can pose a mild inhalation hazard, so the use of a dust mask is suggested. Pool filter grade DE contains crystalline silica that is very dangerous to humans if inhaled, and should never be used for any purpose except as a filtering agent in swimming pools.

\section{Kaolin Clay}

This naturally occurring clay mineral (aluminum silicate) is finely processed so that it can be mixed with water and sprayed evenly onto leaves, stems, and fruit. It leaves a powdery white film (Figure 7) that helps prevent both insect damage and sun scorch from heat and intense sunlight. Kaolin clay can also help deter insects as a mildly irritating physical barrier by repelling them from feeding and laying eggs, or by making plants difficult to recognize. While kaolin is not toxic to humans, heavy use may be harmful to beneficial insects that also need to live on the plants. Complete coverage of the plant and reapplication after heavy rains are necessary for this treatment to be effective.

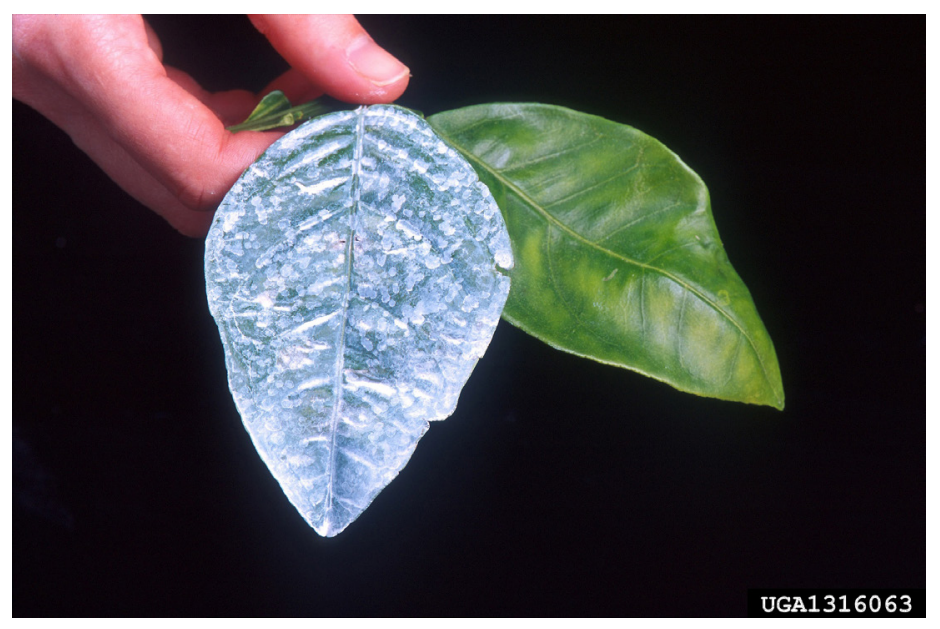

Figure 7. The citrus leaf on the left was sprayed with a kaolin clay product as a deterrent to Diaprepes root weevils.

Credits: Peggy Greb, USDA Agricultural Research Service, used here under Creative Commons license CC BY 3.0 US. Source: bugwood.org

\section{Sulfur}

Sulfur is thought to be the oldest known pesticide in current use and dates back to the Roman era. It can be used as a dust, fumigant, wettable powder, paste, or liquid. Sulfur is used primarily for disease control (see the "Disease Management with Natural Products" section), but it can also help with control of mites, psyllids, and thrips. However, natural enemies such as predatory mites and parasitoids are susceptible as well. Most pesticidal sulfur is labeled for vegetables (e.g., beans, potatoes, tomatoes, and peas) and fruit crops (e.g., grapes, apples, pears, cherries, peaches, plums, and prunes), but some crops, such as cucurbits and raspberries, may not appear on a label because they are easily damaged by sulfur. Sulfur is considered nontoxic to mammals, but it may irritate skin or eyes.

Sulfur has the potential to damage plants in dry, hot weather (when temperatures are near or above $90^{\circ} \mathrm{F}$ one to two days after application) and is incompatible with some other pesticides. Plants sprayed with any kind of oil should not be treated with sulfur for at least two weeks, while some 
plants may require a longer interval of three weeks (citrus) or more.

\section{Iron Phosphate}

Iron phosphate is available under many trade names as a slug and snail bait, and is a safer alternative to metaldehyde baits, which are highly toxic to pets and wildlife. Snails and slugs immediately stop feeding after ingesting this compound and die after several days. Irrigate infested areas before applying and sprinkle (do not pile) the bait granules in late afternoon or evening (slugs and snails are most active on cloudy days or at night). Avoid watering afterwards so that the bait does not dissolve.

\section{Microbial Insecticides}

Microbial insecticides are a category of biopesticides that contain microorganisms (including viruses, bacteria, fungi, protozoa, or nematodes) or the natural toxins they produce. Microbials usually target a specific category or life stage of insect pest (e.g., caterpillars) and therefore pose a reduced risk to nontarget insects or mites. They are not pathogenic to humans, pets, or wildlife. They can successfully be used alongside conventional insecticides and may be particularly useful for their short pre-harvest interval (PHI) on edible plants. Some contain live organisms and may need special conditions prior to application (e.g., insect-parasitic nematodes), while others can be formulated as sprays, dusts, liquid drenches, liquid concentrates, wettable powders, or granules. The more common products, such as Bacillus thuringiensis $(\mathrm{Bt})$ and spinosad, are readily available at retail garden centers, and insect-parasitic nematodes are sold by several online vendors. Others can be difficult to find or are cost-prohibitive. When using microbial insecticides, it is particularly important to understand the limitations and strengths of different products. Always read the entire label to learn how and when to apply them, since heat, sunlight, and dry conditions can reduce effectiveness.

\section{Bacillus thuringiensis (Bt)}

Bacillus thuringiensis (Bt) is a naturally occurring bacterium found in soil, fresh water, and on plant surfaces. Bt products are the most commonly used microbial insecticides. Different subspecies are now available that can target specific pest groups without harming other organisms.

Products include the resting spores of $\mathrm{Bt}$ and the crystalline proteins (Bt toxins) they produce. When an insect ingests Bt or the Bt toxins, the proteins bind to the gut receptors of the insect and cause it to stop feeding and die within a few days. The downside to $\mathrm{Bt}$ is that it is rapidly broken down by sunlight (UV), which means frequent applications may be necessary for some pests.

Before selecting a Bt product, it is important to identify the target pest and know which life stage the Bt will target. For example, Bacillus thuringiensis var. kurstaki (Bt-k) is toxic to caterpillars, but not adult moths. Common caterpillars that Bt var. kurstaki effectively kills include the fall webworm, cabbage looper, bagworm, tomato/ tobacco hornworm, Io moth, and oleander caterpillars. However, it is not very effective against the corn earworm, squash vine borer, or cutworms. In recent years, other Bt varieties have been developed that target other pest groups like fly larvae (mosquitoes, black flies, and fungus gnats) (Bacillus thuringiensis ssp. israelensis [Bti]); wax moth larvae in honeybee hives (B. thuringiensis ssp. aizawai); and beetles (B. thuringiensis ssp. san diego, B. thuringiensis ssp. tenebrionis, and B. thuringiensis ssp. galleriae). Recent UF/ IFAS research found that Bt ssp. galleriae effectively reduces Sri Lanka weevil damage on hibiscus shrubs compared to untreated plants (IR-4 2017). Bt products are especially popular among homeowners because of their efficacy, price, and minimal risk to beneficial insects.

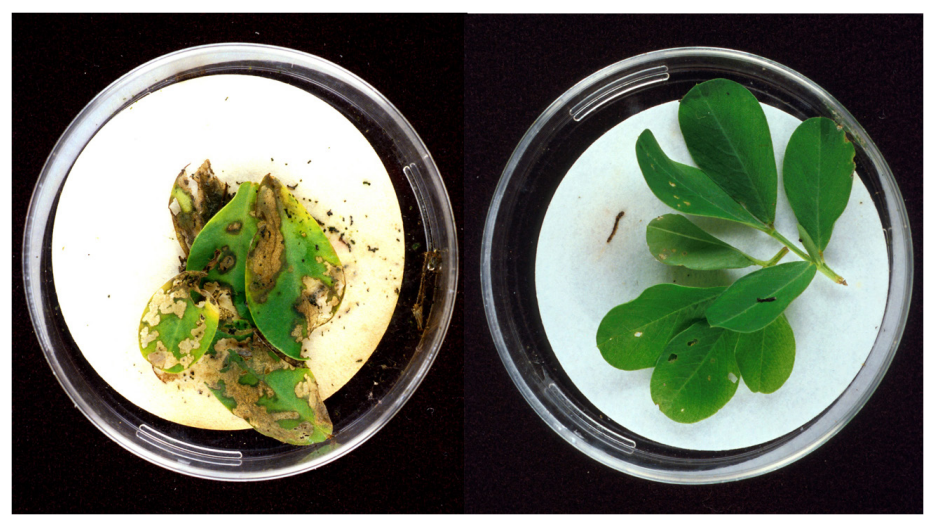

Figure 8. Lesser cornstalk borer larvae severely damaged unprotected peanut leaves (left) while those feeding on Bt-protected leaves quickly ceased feeding, crawled off, and died.

Credits: Herb Pilcher, USDA ARS, Images K8664-1+2

\section{Spinosad}

One of the more familiar and commonly used microbial products is spinosad, which is also derived from a species of soil bacteria, Saccharopolyspora spinosa. Much like Bt, this bacterium produces an insecticidal toxin during fermentation. Spinosad is relatively broad-spectrum and controls a wider range of pests than other microbials, including caterpillars, leafminers, flies, thrips, beetles, and spider mites. Spinosad attacks the nervous systems of insects that come into contact with or ingest it. Feeding stops within minutes and death occurs within two days. When 
used correctly, it has low to moderate toxicity to beneficial organisms and very low toxicity to mammals and wildlife. It is highly toxic to bees when the spray is wet, but dry residues have minimal effect. Therefore, applications should be made during the early morning or late evening, or at night when pollinators are not actively foraging.

\section{Other Bacterial Insecticides}

Chromobacterium subtsugae produces fermentation chemicals that act as a stomach poison and feeding repellent and reduce reproduction in a broad range of insects and mites. Recent UF/IFAS pest control trials have found that this bacterial product works well against foliar feeding beetles (IR-4 2017). It is relatively safe for beneficial insects and approved for organic use by OMRI, but it should still be used carefully to minimize toxic effects to bees, aquatic invertebrates, and soil-dwelling organisms.

Burkholderia is a diverse group of bacteria known for their effects on insects, fungi, nematodes, and plant interactions. A few of these have been commercialized as biocontrols, such as Burkholderia spp. strain A396. These products contain heat-killed cells of the bacteria and their fermentation solids. One is labeled for control of a wide range of caterpillars, as well as suppression of other foliar-feeding, sucking pests such as aphids, stink bugs, thrips, and spider mites. A separate product containing the same strain is labeled for organic nematode control.

The bacteria Paenibacillus popilliae and Paenibacillus lentimorbus cause milky spore disease in beetle larvae or white grubs. Products containing these bacteria are used against Japanese beetle grubs in lawns; however, the efficacy of these products on other grub species is inconsistent or poor. Japanese beetle is not present in Florida, so these products are not recommended for use in the state.

\section{Fungi}

Insect-parasitic fungi thrive in moisture (humidity and rainfall), which favors the germination of fungal spores that penetrate insect bodies and produce toxins that kill the insect. Thus, unlike bacterial and viral pathogens, fungi do not need to be consumed by the insect. There are many groups of insect-parasitic fungi, including species of Isaria (formerly Paecilomyces), Hirsutella, Cordyceps, Metarhizium (formerly Nomuraea), and Beauveria. Of these, Beauveria bassiana is one of the few fungal products available to homeowners. This pathogen naturally occurs in soils, so many soil-dwelling insects may be naturally tolerant to it. Therefore, most commercially available products are labeled for use against foliar-feeding pests such as aphids, thrips, whiteflies, beetles, and spider mites. The pest must come into contact with the product for infection to occur. Death may take several days, so a reduction in the overall pest population can be slow. However, the fungus has an advantage-the downy mold growing from dead insects provides millions of new spores and resulting control of subsequent pest generations or seasons.

Some insect-parasitic fungi are not available for purchase but occur naturally in Florida. During cool, rainy weather, Aschersonia fungi (Figure 10) attack and successfully control several species of whitefly. Unfortunately, the conspicuous, fried egg-like spots formed on each whitefly are often confused for a plant disease or insect pest. However, the fungus causes no damage to the plant and only spreads within the whitefly infestation.

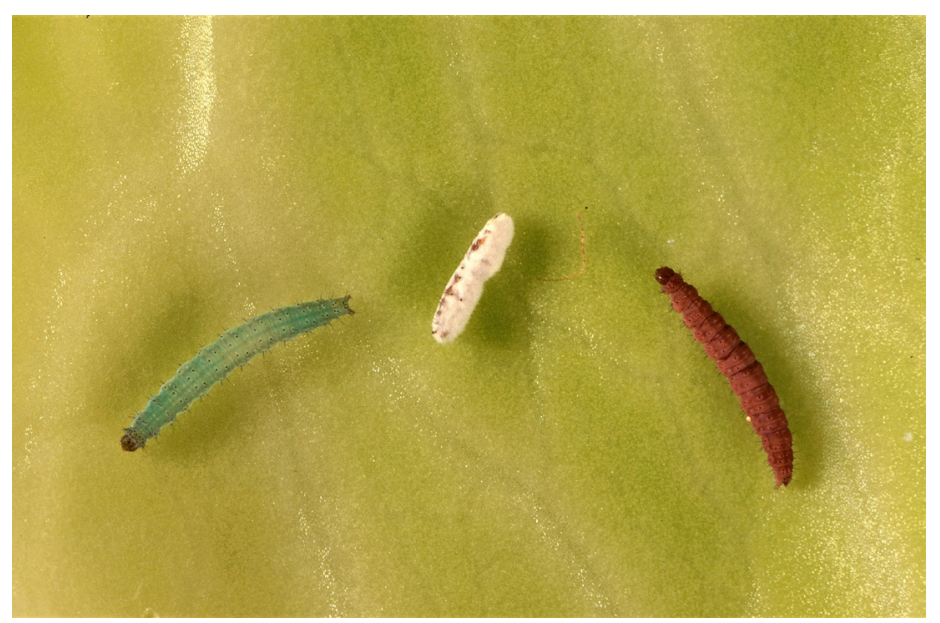

Figure 9. The green diamondback moth larva on the left is alive and healthy. The reddish one on the right was recently killed by Beauveria bassiana spores. The one in the middle is covered with spores that have erupted from within.

Credits: Keith Weller, USDA Agricultural Research Service

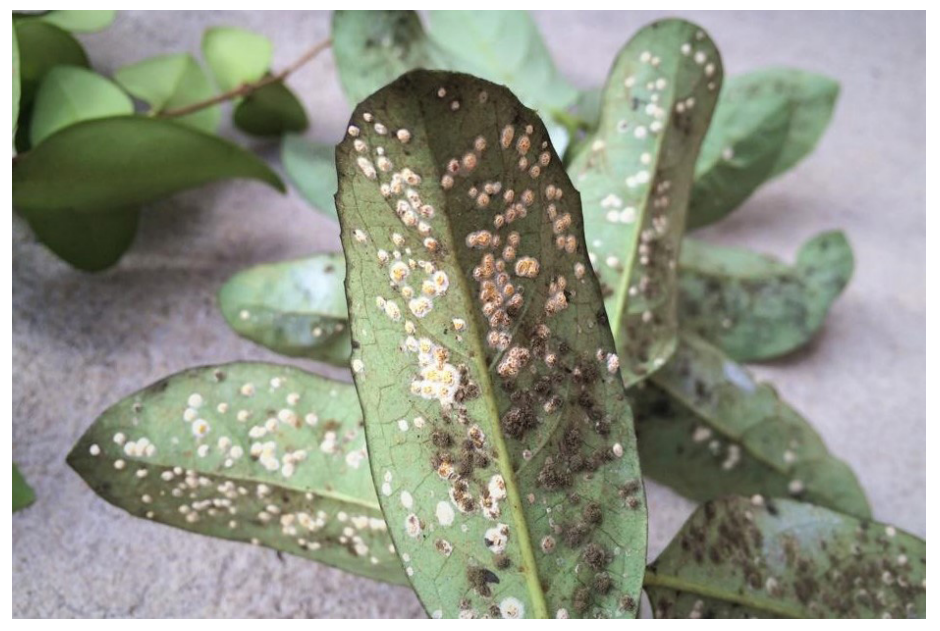

Figure 10. A whitefly infestation colonized by Aschersonia fungus, allowing the shrubs to make a full recovery.

Credits: Wendy Elicati, Alachua, FL 


\section{Microsporidia}

Microsporidium fungi are pathogens which naturally infect a wide range of insect hosts. These pathogens are known for the debilitating effects they have on insects, such as reduced appetite and reproduction. One organism, Antonospora locustae (formerly Nosema locustae), is a weak pathogen that specifically targets grasshoppers. Although commercial A. locustae products are labeled for use in the home garden, scientific evidence indicates they are more appropriate and effective at reducing grasshopper populations in large-scale use, such as in pastureland.

\section{Insect-Parasitic (Entomopathogenic) Nematodes}

Although not truly microbial, these nematodes (roundworms) are used much like microbials and are often referred to as biopesticides. Steinernema and Heterorhabditis species are common beneficial nematodes that are commercially available. They infect the soil-dwelling insect host by entering through body openings and releasing bacteria (Xenorhabdus and Photorhabdus spp.) into the insect's blood (hemolymph). The bacteria cause the insect to die in one to several days. After reproducing, young nematodes exit the dead insect and search (by swimming through soils) or wait for a new host. Products containing parasitic nematodes have been developed to control white grubs in turfgrasses, as well as root weevil larvae and similar soildwelling pests that attack lawn and garden plantings. They work best in sheltered or undisturbed environments with high moisture levels. Before purchasing insect-parasitic nematodes, it is important to identify both the target pest and the species of nematode because the nematodes have different host preferences.

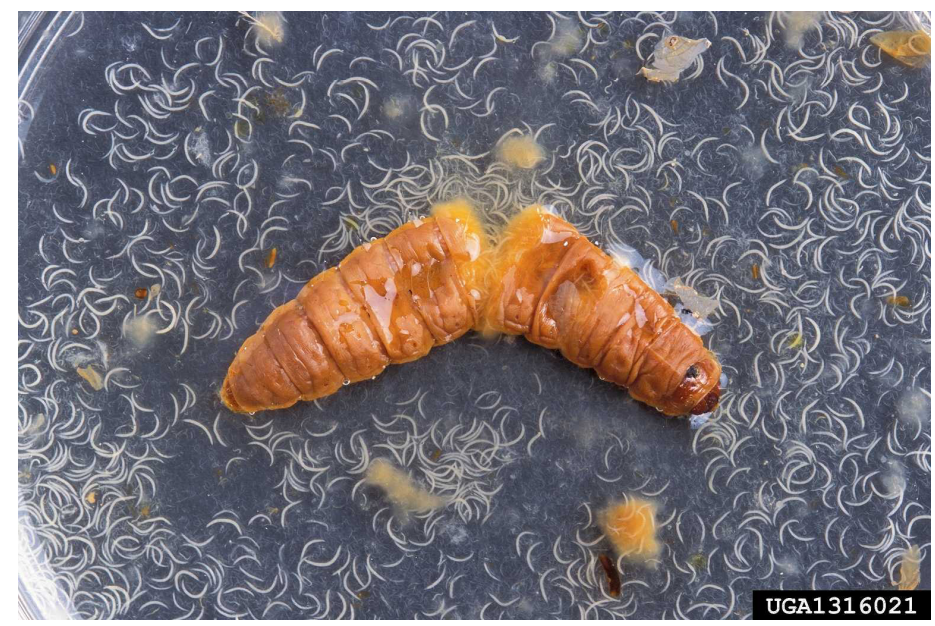

Figure 11. Infective nematodes emerging from a dead moth pupa. This nematode species, Heterorhabditis bacteriophora, is able to attack immature stages of many beetle and moth pests.

Credits: Peggy Greb, USDA Agricultural Research Service, used here under Creative Commons license CC BY 3.0 US. Source: bugwood.org
For more information, see EDIS document EENY-530, Entomopathogenic Nematodes (Nematoda: Rhabditida: families Steinernematidae and Heterorhabditidae) (http:// edis.ifas.ufl.edu/in944).

\section{Viruses}

Several naturally occurring insect viruses have been developed and registered for use as insecticides. In particular, baculoviruses, including nuclear polyhedrosis viruses (NPV), have been widely used by the US Forest Service against major forest pests such as gypsy moth and Douglasfir tussock moth caterpillars. The advantage of insect viruses is that they are specific to their caterpillar or sawfly hosts and can persist in the environment to infect future generations of caterpillars. Unfortunately, producing the viruses at commercial scale is both difficult and expensive. Few products are currently available, and most of these are not registered for use in Florida.

\section{Disease Management with Natural Products}

To effectively manage plant diseases with natural products, keep a few guiding principles of disease management in mind:

1. Healthy and resistant plants are the best defense. Follow the "right plant, right place" rule when buying and planting, and use good cultural practices.

2. The products below should be used to prevent rather than cure diseases. Applying preventive products to plants that are already diseased is a waste of time and money. Early detection and removal of infected plants or plant parts should precede applications of chemicals.

The following is a limited list of natural fungicides that are readily available to homeowners.

\section{Biofungicides}

Several naturally occurring microorganisms are used to suppress fungal and bacterial diseases. The most common is Bacillus subtilis. When applied as a seed treatment or soil drench, this bacterium colonizes roots and outcompetes root-infecting fungi. Bacillus subtilis strain QST 713 is used as a foliar application against powdery mildew and as a suppressant against other foliar diseases. Several other Bacillus species, such as Bacillus amyloliquefaciens strain D747, may help suppress a wide variety of lawn and garden diseases. Another bacterium, Streptomyces lydicus, is also used to suppress lawn and vegetable diseases. The fungus 
Trichoderma harzianum is used to prevent damping-off diseases, which attack seeds and vulnerable roots and stems of seedlings. In general, these products work by outcompeting the pathogen or by producing a substance that inhibits its growth or kills it. To be effective, they need to colonize the plant's roots or foliage before an infection occurs.

\section{Copper}

Copper has been used to protect crops from disease since the late 1800s, when a formulation called Bordeaux mixture became the first major fungicide used worldwide. Bordeaux mixture combined lime (calcium hydroxide) with copper sulfate to neutralize its acidity and reduce plant damage. Today, there are many copper-based products available and some are OMRI-listed. Although considered fungicides, they can also be effective against bacterial diseases. Copper prevents infection by acting as a barrier between the plant surface and the pathogen. Plants need copper as a micronutrient, but only in small amounts obtained naturally from soil. Copper sprays do not move inside the plant. Different active ingredients (copper hydroxide, copper sulfate, copper octanoate, etc.) have different properties, so follow label instructions closely. For example, copper sulfate is an older, water-soluble form that can easily damage plants and is highly toxic to humans, other mammals, and aquatic environments. Copper also becomes more phytotoxic under acidic conditions, so the $\mathrm{pH}$ of a spray solution should be considered. Newer, water-insoluble forms (called "fixed" coppers) provide longer residual protection and have reduced risk of phytotoxicity. However, these still vary in their toxicity to bees, and all are highly toxic to aquatic wildlife. To minimize plant injury, apply coppers when the plant surfaces can dry quickly. The residues of copper fungicides can also act as feeding deterrents for slugs and snails.

\section{Potassium Bicarbonate and Sodium Bicarbonate}

Although labeled for powdery mildew and a wide variety of other diseases, fungicides containing sodium bicarbonate (baking soda) and potassium bicarbonate do not offer a high level of disease control. However, they have minimal mammalian and environmental toxicity. They also provide some protection when they are used preventively, or when disease levels are low. They work primarily by raising the $\mathrm{pH}$ of the leaf surface, creating an environment that is too alkaline for foliar diseases to germinate and grow. Potassium bicarbonate is more effective and less phytotoxic than sodium bicarbonate, which can cause damage to foliage in solutions of $1 \%$ or more, or with repeated applications due to the buildup of sodium. If used carefully, sodium bicarbonate can be made more effective by applying in a mixture with horticultural oil. Since bicarbonates are water-soluble, they must be reapplied after rainfall.

\section{Sulfur}

Sulfur can be an effective fungicide against powdery mildew, rusts, leaf blights, fruit rots, and some other plant diseases. It works primarily by preventing spore germination, so it should be applied preventively for good results. See the previous section on sulfur for precautions regarding its use in the garden.

In the past, a more commonly used form was lime sulfur, a mixture of hydrated lime (calcium hydroxide) and sulfur. This compound is much more effective against diseases than sulfur alone, but it still has phytotoxicity risks. It is also highly caustic, corrosive to the eyes, and harmful if swallowed, inhaled, or absorbed by the skin. For these reasons, it is no longer commonly sold at garden centers and is primarily used for commercial organic production.

\section{References}

Antonious, G. F., J. E. Meyer, J. A. Rogers, and Y. Hu. 2007. "Growing hot pepper for cabbage looper, Trichopulsia ni (Hübner) and spider mite, Tetranychus urticae (Koch) control." Journal of Environmental Science and Health Part B 42: 559-567.

Antonious, G. F., J. E. Meyer, and J. C. Snyder. 2006. "Toxicity and repellency of hot pepper extracts to spider mite, Tetranychus urticae Koch." Journal of Environmental Science and Health Part B 41(8): 1383-1391. doi: 10.1080/0360123060096419.

Arizona Cooperative Extension. 2006. "Diatomaceous earth... A reduced-risk pesticide." Pest Press, Issue 6, September 2006. https://cals.arizona.edu/urbanipm/ pest_press/2006/september.pdf

Arthurs, S. P., L. F. Aristizábal, and P. B. Avery. 2013. "Evaluation of entomopathogenic fungi against chilli thrips, Scirtothrips dorsalis." Journal of Insect Science 13(31): 1-16.

Baldwin, R. 2008. "Soaps as insecticides." In Encyclopedia of Entomology, edited by J. L. Capinera. 3432-3440. Heidelberg, Germany: Springer Science+Business Media B.V.

Beckerman, J. 2008. “Using organic fungicides.” BP-69-W. Purdue University: Purdue Extension. https://www.extension.purdue.edu/extmedia/BP/BP-69-W.pdf 
Bográn, C. E., S. Ludwig, and B. Metz. 2006. “Using oils as pesticides." E-419. Texas A\&M System: AgriLife Extension. http://oaktrust.library.tamu.edu/bitstream/ handle/1969.1/86885/pdf_1192.pdf

Bunch, T. R., C. Bond, K. Buhl, and D. Stone. 2013. "Diatomaceous earth general fact sheet." National Pesticide Information Center, Oregon State University Extension Services. http://npic.orst.edu/factsheets/degen.html

Caldwell, B., E. Sideman, A. Seaman, A. Shelton, and C. Smart. 2013. Resource Guide for Organic Insect and Disease Management, 2 edition. Geneva, New York: Cornell University, New York State Agricultural Experiment Station. http://web.pppmb.cals.cornell.edu/resourceguide/ pdf/resource-guide-for-organic-insect-and-diseasemanagement.pdf

Capinera, J. L. 2018. "Assessment of barrier materials to protect plants from Florida leatherleaf slug (Mollusca: Gastropoda: Veronicellidae)." Florida Entomologist 101(3).

Chalker-Scott, L. 2009. "Baking soda: Will fungi fail and roses rejoice?” MasterGardener (Spring 2009): 2-4. https:// s3.wp.wsu.edu/uploads/sites/403/2015/03/baking-soda.pdf

Cloyd, R. A. 2015. "Explaining azadirachtin and neem." GNP Magazine (November 2015): 10. http://gpnmag.com/ wp-content/uploads/GPNNov_Dr.Bugs_.pdf

Cordova-Kreylos, A. L., L. E. Fernandez, M. Koivunen, A. Yang, L. Flor-Weiler, and P. G. Marrone. 2013. "Isolation and characterization of Burkholderia rinojensis sp. nov., a non-Bcc soil bacterium with insecticidal and miticidal activity." Applied and Environmental Microbiology 79(24): 7669-7678.

Cranshaw, W. S. 2008. "Insect control: Soaps and detergents." Fact Sheet No. 5.547. Colorado State University Extension. http://extension.colostate.edu/docs/pubs/ insect/05547.pdf

Gaskin, J. W., P. Hartel, E. Little, and G. Harris. 2013. "Soil inoculants." Circular 990. University of Georgia College of Agricultural and Environmental Sciences Cooperative Extension. https://secure.caes.uga.edu/extension/publications/ files/pdf/C\%20990_2.PDF

Grasswitz, T. R. 2012. "Selection and use of insecticides for organic production." Guide H-168. New Mexico State University, College of Agricultural, Consumer, and Environmental Sciences. http://aces.nmsu.edu/pubs/_h/H168.pdf
Grewal, P. and R. Georgis. 1999. "Chapter 15: Entomopathogenic nematodes." In Biopesticides: Use and Delivery (Methods in Biotechnology: 5), edited by F. R. Hall and J. J. Menn. Totowa, NJ: Humana Press Inc.

IR-4. 2017. "Ornamental Horticulture Program Research Project, borer and foliar-feeding beetle efficacy." USDA-NIFA Minor Crop Pest Management Program Interregional Research Project \#4. Accessed on September 14, 2018. https:// www.ir4project.org/ehc/ehc-registration-support-research/ env-hort-extension-resources/

Johnson, D. L. 1989. "The effects of timing and frequency of application of Nosema locustae (Microspora: Microsporida) on the infection rate and activity of grasshoppers (Orthoptera: Acrididae)." Journal of Invertebrate Pathology 54: 353-364.

Maia, M. F. and S. J. Moore. 2011. "Plant-based insect repellents: a review of their efficacy, development and testing." Malaria Journal 10(Suppl 1): S11. http://doi. org/10.1186/1475-2875-10-S1-S11

Moreau, T. L., P. R. Warman, and J. Hoyle. 2006. "An evaluation of companion planting and botanical extracts as alternative pest controls for the Colorado potato beetle." Biological Agriculture and Horticulture 23: 351-370.

National Pesticide Information Center. 2001. "Potassium salts of fatty acids (Technical fact sheet).” NPIC. http://npic. orst.edu/factsheets/archive/psfatech.pdf

Onsager, J. A. 1988. "Assessing effectiveness of Nosema locustae for grasshopper control." Montana Agricultural Experiment Station Bulletin 5: 12-16.

Pedigo, L. P. 1999. Entomology and Pest Management, 3 edition. Upper Saddle River, NJ: Prentice Hall.

Peter, K. 2016. "Demystifying copper for disease management." Penn State University, College of Agricultural Sciences. https://agresearch.umd.edu/sites/agresearch.umd.edu/ files/_docs/locations/wye/2016\%20Winter\%20meeting_Copper.pdf

Pundt, L. 2015. “Insecticidal soaps.” University of Connecticut Integrated Pest Management Program. http://ipm. uconn.edu/documents/raw2/800/2015insecticidalsoapfacts heet.pdf 
Schmutterer, H. 1990. "Properties and potential of natural pesticides from the neem tree, Azadirachta indica." Annual Review of Entomology 35: 271-97.

Scott, I. M., H. Jensen, J. G. Scott, M. B. Isman, J. T. Arnason, and B. J. R. Philogène. 2003. "Botanical insecticides for controlling agricultural pests: Piperamides and the Colorado potato beetle Leptinotarsa decemlineata say (Coleoptera: Chrysomelidae)." Archives of Insect Biochemistry and Physiology 54: 212-225.

Stark, J. D. and J. F. Walter. 1995. "Neem oil and neem oil components affect the efficacy of commercial neem insecticides." Journal of Agricultural and Food Chemistry 43: 507-512. https://pubs.acs.org/doi/pdf/10.1021/jf00050a047

Ware, G. W. and D. M. Whitacre. 2000. The Pesticide Book, 6 edition. Willoughby, $\mathrm{OH}$ : MeisterPro Information Resources. 
Table 1. Summary of pesticide properties and primary uses.

\begin{tabular}{|c|c|c|c|}
\hline Product & Type & Mode of Action & Primary Plant Pest(s) Targeted \\
\hline Citrus oils (limonene, linalool) & Botanical insecticide & $\begin{array}{l}\text { Contact poison (nerve } \\
\text { toxins) }\end{array}$ & $\begin{array}{l}\text { Aphids, mites, fire ants, flies, } \\
\text { house crickets, and wasps }\end{array}$ \\
\hline Neem oil (Azadirachta indica) & $\begin{array}{l}\text { Botanical insecticide, preventive } \\
\text { fungicide }\end{array}$ & $\begin{array}{l}\text { Repellent, contact } \\
\text { smothering }\end{array}$ & $\begin{array}{l}\text { Numerous soft-bodied insects } \\
\text { and mites. Powdery mildew. }\end{array}$ \\
\hline $\begin{array}{l}\text { Neem extracts azadirachtin } \\
\text { (Azadirachta indica) }\end{array}$ & Botanical insecticide & $\begin{array}{l}\text { Repellent, insect growth } \\
\text { regulator, direct toxin }\end{array}$ & $\begin{array}{l}\text { Caterpillars, sawflies, flea beetles, } \\
\text { weevils, aphids, leafhoppers, etc. }\end{array}$ \\
\hline $\begin{array}{l}\text { Other plant oils (extracts of garlic, } \\
\text { sesame, herbs, citronella, etc.) }\end{array}$ & Botanical insecticide & $\begin{array}{l}\text { Repellent, contact or } \\
\text { stomach poison }\end{array}$ & $\begin{array}{l}\text { Insecticidal properties and target } \\
\text { pests dependent on the extract }\end{array}$ \\
\hline Horticultural oil (petroleum-based) & Oil insecticide & Contact, smothering & $\begin{array}{l}\text { Numerous soft-bodied insects } \\
\text { and mites, including scales, } \\
\text { aphids, whiteflies, mealybugs }\end{array}$ \\
\hline $\begin{array}{l}\text { Insecticidal soap (potassium salts of } \\
\text { fatty acid) }\end{array}$ & Soap insecticide & $\begin{array}{l}\text { Cuticle and membrane } \\
\text { disruption }\end{array}$ & $\begin{array}{l}\text { Numerous soft-bodied insects } \\
\text { and mites, including soft scales, } \\
\text { aphids, psyllids, whiteflies, thrips, } \\
\text { mealybugs }\end{array}$ \\
\hline $\begin{array}{l}\text { Pyrethrins/Pyrethrum (Chrysanthemum } \\
\text { cinerariaefolium) }\end{array}$ & Botanical insecticide & $\begin{array}{l}\text { Nerve toxin, contact } \\
\text { activity }\end{array}$ & $\begin{array}{l}\text { Many garden insect pests, ants, } \\
\text { roaches, fleas, flies, ticks }\end{array}$ \\
\hline $\begin{array}{l}\text { Hot pepper (extracts from Capsicum } \\
\text { sp.) }\end{array}$ & Botanical repellent & Repellent & Many insects \\
\hline $\begin{array}{l}\text { Diatomaceous earth (silica shells of } \\
\text { diatoms) }\end{array}$ & Mineral insecticide & $\begin{array}{l}\text { Cuticle disruption, } \\
\text { dehydration }\end{array}$ & $\begin{array}{l}\text { Ants, fleas, bed bugs, } \\
\text { cockroaches, millipedes, } \\
\text { sowbugs, and other small, soft- } \\
\text { bodied insects }\end{array}$ \\
\hline Kaolin clay (aluminum silicate) & Mineral repellent & $\begin{array}{l}\text { Feeding deterrent, } \\
\text { repellent }\end{array}$ & Various foliage-dwelling insects \\
\hline $\begin{array}{l}\text { Sulfur (by-product of natural gas, } \\
\text { petroleum refinement) }\end{array}$ & $\begin{array}{l}\text { Mineral insecticide, miticide, } \\
\text { fungicide }\end{array}$ & Contact poison & $\begin{array}{l}\text { Mites, psyllids, thrips; powdery } \\
\text { mildew, rust, leaf blight, fruit rots }\end{array}$ \\
\hline Slug and snail baits (iron phosphate) & Mineral molluscicide & Stomach poison & Slugs and snails \\
\hline Bt-k (Bacillus thuringiensis var. kurstaki) & Microbial insecticide & Stomach poison & $\begin{array}{l}\text { Many caterpillars (e.g., fall } \\
\text { webworm, loopers, bagworms, } \\
\text { hornworms) }\end{array}$ \\
\hline Bt (other Bacillus thuringiensis varieties) & Microbial insecticide & Stomach poison & $\begin{array}{l}\text { Fly larvae (mosquitoes, fungus } \\
\text { gnats), wax moth larvae, some } \\
\text { beetles }\end{array}$ \\
\hline Spinosad (Saccharopolyspora spinosa) & Microbial insecticide & $\begin{array}{l}\text { Contact and stomach } \\
\text { poison }\end{array}$ & $\begin{array}{l}\text { Thrips, sawflies, caterpillars, flies, } \\
\text { beetles, spider mites }\end{array}$ \\
\hline Chromobacterium subtsugae & Microbial insecticide & Stomach poison, repellent & $\begin{array}{l}\text { Multiple insects and mites, } \\
\text { especially leaf-feeding beetles }\end{array}$ \\
\hline Beauveria bassiana & Microbial insecticide & $\begin{array}{l}\text { Fungus directly infects } \\
\text { insects }\end{array}$ & $\begin{array}{l}\text { Foliar-feeding insects (e.g., } \\
\text { aphids, thrips, whiteflies, beetles, } \\
\text { spider mites) }\end{array}$ \\
\hline $\begin{array}{l}\text { Nematodes (Steinernema spp. and } \\
\text { Heterorhabditis spp.) }\end{array}$ & Microorganisms & $\begin{array}{l}\text { Directly infect and kill } \\
\text { insects }\end{array}$ & $\begin{array}{l}\text { Many lawn and soil-dwelling } \\
\text { grubs }\end{array}$ \\
\hline $\begin{array}{l}\text { Bacillus subtilis, other Bacillus spp., } \\
\text { Streptomyces sp., Trichoderma sp. }\end{array}$ & Microbial fungicides & $\begin{array}{l}\text { Colonize plants and } \\
\text { outcompete pathogens }\end{array}$ & $\begin{array}{l}\text { Damping-off seeding diseases; } \\
\text { wide variety of garden and lawn } \\
\text { diseases }\end{array}$ \\
\hline Copper compounds & Mineral fungicide and bactericide & Protectant barrier & $\begin{array}{l}\text { Many fungal and bacterial } \\
\text { diseases }\end{array}$ \\
\hline $\begin{array}{l}\text { Potassium bicarbonate, sodium } \\
\text { bicarbonate }\end{array}$ & Mineral fungicide & Protectant alkaline barrier & Powdery mildew \\
\hline
\end{tabular}

